\title{
DSC study of hydration and water-holding behaviour of cultured in vitro mycelium and naturally grown fruiting bodies of freeze-dried Boletus badius, Agaricus bisporus and Cantharellus cibarius
}

\author{
Przemysław Talik ${ }^{1}$ · Joanna Piwowarczyk ${ }^{1}$ • Bożena Muszyńska² • Urszula Hubicka ${ }^{1}$
}

Received: 10 December 2018 / Accepted: 30 March 2020 / Published online: 11 April 2020

(c) The Author(s) 2020

\begin{abstract}
The aim of the study was to calculate the content of non-freezing water (NFW) as well as amount of water associated with the evaporation process $\left(N_{\mathrm{ev}}\right)$ in the chosen species of fungi. The study focused on lyophilized in vitro mycelium and commonly cultivated mushrooms Agaricus bisporus, Boletus badius and Cantharellus cibarius. Both NFW and $N_{\mathrm{ev}}$ were examined by means of differential scanning calorimetry (DSC). The above-mentioned types of water are important components of the state diagram that is a kind of functional graph helping in identifying food stability during storage and selecting suitable conditions of temperature and moisture content for processing. The content of non-freezing water in all examined samples ranged between 0.19 and $0.31 \mathrm{~g} \mathrm{~g}^{-1}$. The estimated amount of water associated with the evaporation process was found to be between 0.05 and $0.13 \mathrm{~g} \mathrm{~g}^{-1}$. The obtained results were variable and highly dependent on fungus species, origin (in vitro mycelium vs cultivated) and content of accumulated metals. The influence of these factors is discussed. In order to determine statistical significance, selected samples were measured at least 5 times; the relative standard of deviation (\%RSD) did not exceed 4.45 of measured enthalpies. In the group of mycelium from in vitro cultures, the DSC method was used for the first time. The publication also compared the NFW and $N_{\mathrm{ev}}$ values with those obtained for naturally grown fruiting bodies of the same species.
\end{abstract}

Keywords DSC $\cdot$ Non-freezing water $\cdot$ Water evaporation $\cdot$ Agaricus bisporus $\cdot$ Cantharellus cibarius $\cdot$ Boletus badius

\section{Introduction}

State diagram is a kind of graph identifying and visualizing different regions of food as a function of water (or solids) content and temperature. In other words, it is an useful tool showing the complex changes of food while water content and/or temperature is changed. It is also suitable in selecting optimal conditions for further food processing. The idea of state diagram combines water activity and glass transition concepts and was probably used for the first time by Levine et al. [1], widely exploited by other scientific research

Przemysław Talik

mftalik@cyf-kr.edu.pl

1 Department of Inorganic and Analytical Chemistry, Medical College, Pharmaceutical Faculty, Jagiellonian University, 9 Medyczna St., 30-688 Krakow, Poland

2 Department of Pharmaceutical Botany, Medical College, Pharmaceutical Faculty, Jagiellonian University, 9 Medyczna St., Krakow, Poland groups [2-4] and then modified by Rahman [5]. One of the important components of state diagram is non-freezing water (NFW) [6-10], defined as a strongly bounded fraction that is not able to crystallize $[11,12]$ and where typical exothermic peak cannot be calorimetrically measured. The appropriate low water contents found in the hydrophilic polymer are considered to be non-freezing [11]. Water binding is associated with hydrogen bonding and the presence of "nanocavities" formed in the matrix [11]. Depending on water concentration and grade of polymer chains, it can lead to form new reversible and stable structures [13]. Moreover, content of NFW distinctly increases when ionic groups are present in the polymer structure [14]. Berthold et al. [15] concluded that the counter-ion favouring water adsorption is $\mathrm{Li}^{+}$, followed, in decreasing order of efficiency, by $\mathrm{Na}^{+}, \mathrm{K}^{+}, \mathrm{Ca}^{2+}$ and $\mathrm{H}^{+}$.

Generally, the storage of food is associated with its initial processing. Very often, this involves vaporization of water during a thermal drying, whereas other methods such as sublimation are less frequently used. Removing of 
free water is held at a temperature up to $100{ }^{\circ} \mathrm{C}$. However, vaporization of water strongly attached to polymer chains by hydrophilic groups could be observed at temperature higher than $100{ }^{\circ} \mathrm{C}$. For example, for samples containing both non-freezing and free water, Hatakeyama et al. [16] reported two states of vaporization in TG studies. The first was terminating lower than $100{ }^{\circ} \mathrm{C}$, and the second was ranging from 147 to $197{ }^{\circ} \mathrm{C}$. An agreement between the results of differential thermal analysis and the mass decrease obtained by TG was confirmed in other investigations of the same author [17]. Thus, in a similar way as non-freezing, the water associated with the evaporation process $\left(N_{\mathrm{ev}}\right)$ can be considered as water that remains in the material at temperatures significantly exceeding $100{ }^{\circ} \mathrm{C}$ or even $140{ }^{\circ} \mathrm{C}$. The measured enthalpy of vaporization $(\Delta H)$ is considered as the energy required to evaporate absorbed molecules of water from hydrated material and can be normalized using mass of either dry sample or water. In this research, we used the first method, since it is recommended by Kučerík et al. [18]. In his opinion, it reflects better the mutual interactions between polysaccharide chains and water.

In this way, evaporation of water can be an additional approach to characterize the hydration and water-holding behaviour of mushroom materials. It is suggested that $N_{\mathrm{ev}}$ content could be an useful complement of the state diagram in the part describing water evaporation from the liquid and solid phases. Rahman illustrated this segment with respective lines MD and DP (Fig. 1 [5]).

Selected edible mushroom species, both in vitro and natural origin, as Agaricus bisporus, Boletus badius and Cantharellus cibarius, are known as highly valued source of vitamins (especially riboflavin, ergocalciferol), bioelements (for example, selenium, magnesium, copper, iron, calcium, zinc and potassium) [19-25] and antioxidant substances (phenols, flavonoids, terpenes, steroids, carotenoids) [26-28]. For that reason, optimal drying and freezing data for further processing are necessary in the maintenance of chemical and microbiological stability of mushrooms under study.

The aim of the study was to calculate the content of non-freezing water NFW as well as amount of water associated with the evaporation process $N_{\mathrm{ev}}$ in the chosen species of lyophilized in vitro mycelium and commonly cultured mushrooms Agaricus bisporus, Boletus badius and Cantharellus cibarius. In the research, the differential scanning calorimetry method was used. The technique was previously applied in various synthetic and semi-synthetic polysaccharides [14, 29-32]. In the group of mycelium from in vitro cultures, the method was used for the first time. The publication also compared the NFW and $N_{\mathrm{ev}}$ values with those obtained for naturally grown fruiting bodies of the same species.

\section{Materials and methods}

\section{Mushrooms samples}

The in vitro mycelium material of Agaricus bisporus, Cantharellus cibarius and Boletus badius was obtained from Department of Pharmaceutical Botany, Pharmaceutical Faculty, Medical College, Jagiellonian University, as a gift. The naturally grown fruiting bodies of these mushrooms were purchased in local vegetable shops.

\section{Sample preparation}

The freeze-dried in vitro mycelium and naturally grown fruiting bodies of Agaricus bisporus, Cantharellus cibarius and Boletus badius material were additionally dried over phosphorus $(V)$ oxide in desiccator. After 6-week-long storage, the mushroom material (about $28-46 \mathrm{mg}$ ) was placed in sample pans and the excess of Milli-Q water was added. In order to obtain the desired water content, defined by a $W_{\mathrm{c}}$ factor (the ratio of mass of water to mass of dry mushroom), the water was allowed to evaporate slowly at room temperature. In further investigations, the samples of known $W_{\mathrm{c}}$ ranging from 0.2 to $3.5 \mathrm{~g} \mathrm{~g}^{-1}$ (18 different concentrations) were used. The homogeneous hydrated material of about 8-9 mg was quickly transferred to aluminium sample pans and immediately hermetically sealed. To reach an equilibrium state, all obtained samples were conditioned at room temperature for about $30 \mathrm{~h}$. The crucibles with mushroom material were weighted before and after each measurement to insure that there is no loss of mass.

In order to protect from spontaneous reactions with water, the aluminium sample pans were previously passivated in an autoclave at $120^{\circ} \mathrm{C}$ for $3 \mathrm{~h}$.

\section{DSC analysis}

The DSC experiments were performed in nitrogen atmosphere with a flow rate of $50 \mathrm{~mL} \mathrm{~min}{ }^{-1}$, using EXSTAR DSC 7020 apparatus (Hitachi Inc.) equipped with immersion cooler ULSP 90 (ULSP BV). The DSC instrument was calibrated with $99.9999 \%$ indium and high purity Milli-Q water. The measurements were carried out using the following thermal protocol: starting at $20^{\circ} \mathrm{C}$, cooling from 20 to $-60{ }^{\circ} \mathrm{C}$ at $3{ }^{\circ} \mathrm{C} \mathrm{min}{ }^{-1}$, isothermal at $-60^{\circ} \mathrm{C}$ for $5 \mathrm{~min}$, and heating from -60 to $20^{\circ} \mathrm{C}$ at $3^{\circ} \mathrm{C} \mathrm{min}^{-1}$. The evaporation studies were realized using the same samples; however, in each run, covering lids were perforated and the nitrogen flow rate was reduced to about $5 \mathrm{~mL} \mathrm{~min}^{-1}$. The thermal procedure was as follows: starting at $20^{\circ} \mathrm{C}$, cooling from 20 to $-40{ }^{\circ} \mathrm{C}$ at $5{ }^{\circ} \mathrm{C} \mathrm{min}-1$, and heating from -40 to $150{ }^{\circ} \mathrm{C}$ at 
$3{ }^{\circ} \mathrm{C} \min ^{-1}$. The purpose of freezing the sample pans before the evaporation investigations was to identify the onset of evaporation easier.

The measured enthalpies both of melting and evaporating were first normalized to the mass of the dry mushroom material and then plotted against the respective water concentration $\left(W_{\mathrm{c}}\right)$. In this way, expected linear dependences $\Delta H=f\left(W_{\mathrm{c}}\right)$ were obtained. The NFW and $N_{\mathrm{ev}}$ contents were estimated by extrapolation $\Delta H$ to $0(\Delta H=0)$.

The interpretation of DSC experiments was performed using Muse Measurement v 9.21U software. Due to observed baseline shifts and nonlinearities, the determination of melting as well as evaporating enthalpies was carried out using a T-Slice Analysis (Integral Tangential). In order to reduce experimental errors, DSC runs were repeated three times and averaged. To determine statistical significance, selected samples were measured at least 5 times. The results were expressed as the relative standard deviation (\%RSD) and did not exceed 4.45 of measured enthalpies.

\section{Results and discussion}

Figure 1 shows a representative DSC run, obtained from hydrated sample of mushroom under study. One can see that immediately after melting, the vaporization process is starting. This interesting phenomenon is marked with the red circle. The subfigure (A) additionally emphasizes it. A similar shape of curves was also reported by other authors $[13,30,32,33]$.

The typical stack of DSC curves, illustrating changes in enthalpies with various concentrations of water, obtained during the melting and evaporating processes is displayed in Fig. 2. As it was expected, with increasing water content (a)
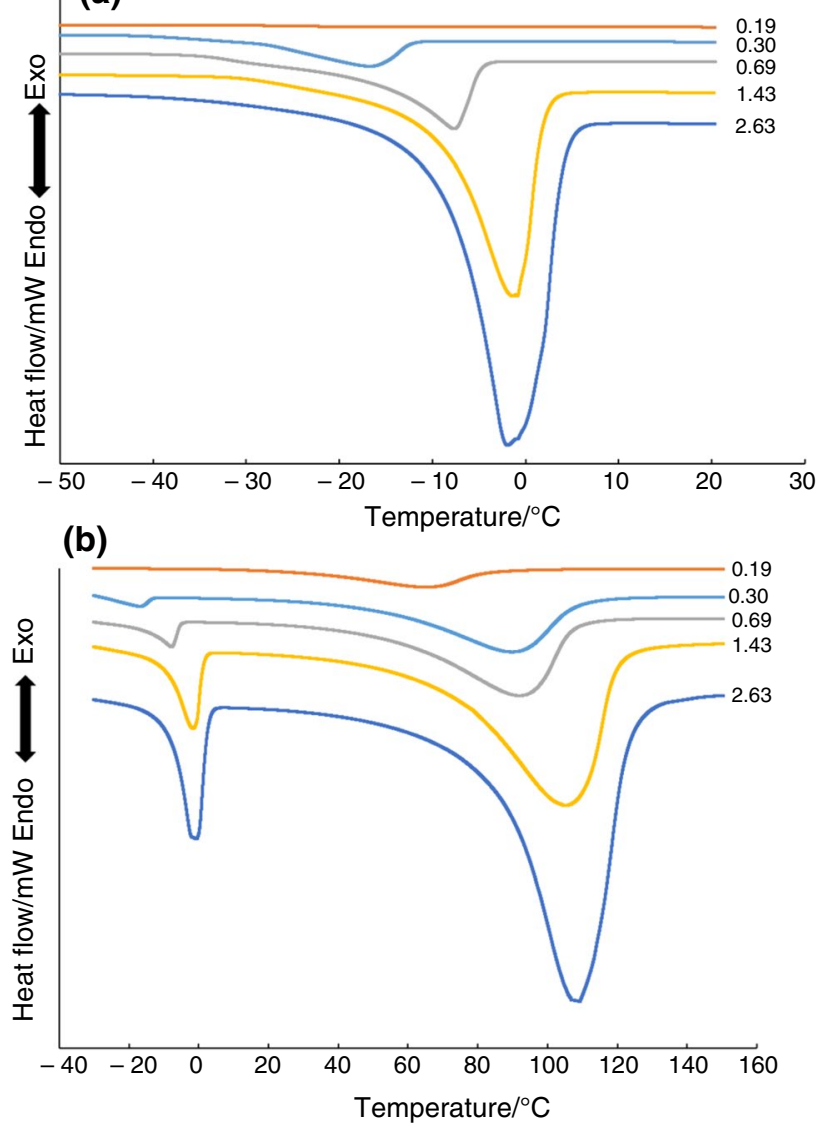

Fig. 2 Representative DSC runs of melting (a) and evaporating (b); displayed DSC curves were obtained from Agaricus bisporus cultured samples; the numbers beside each curve are associated with water content $W_{\mathrm{c}}$
Fig. 1 Typical and representative example of DSC run observed during the studies. The red circle points the area of ending of the melting process and the immediate start of evaporation process - the subfigure (A) additionally emphasizes observed phenomenon. Displayed curve was obtained from in vitro mycelium of freezedried Boletus badius with water content $W_{\mathrm{c}}=1.3 \mathrm{~g} \mathrm{~g}^{-1}$. The evaporation studies were realized using the same samples; however, in each run, covering lids were perforated

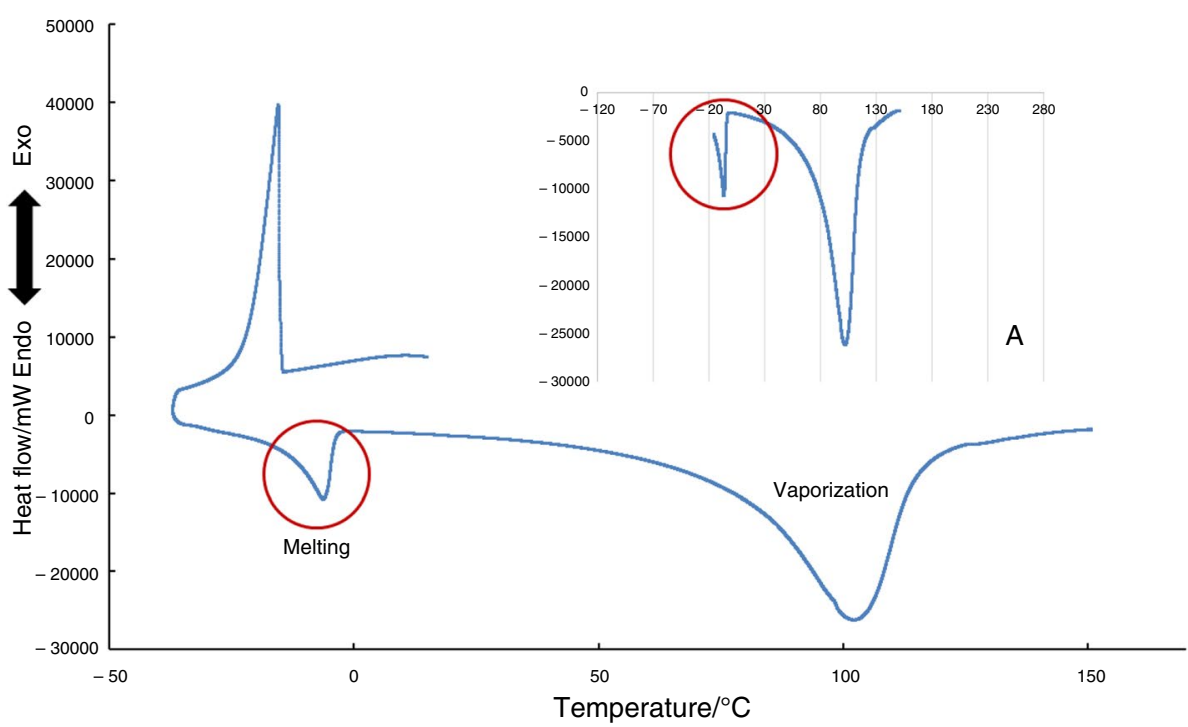




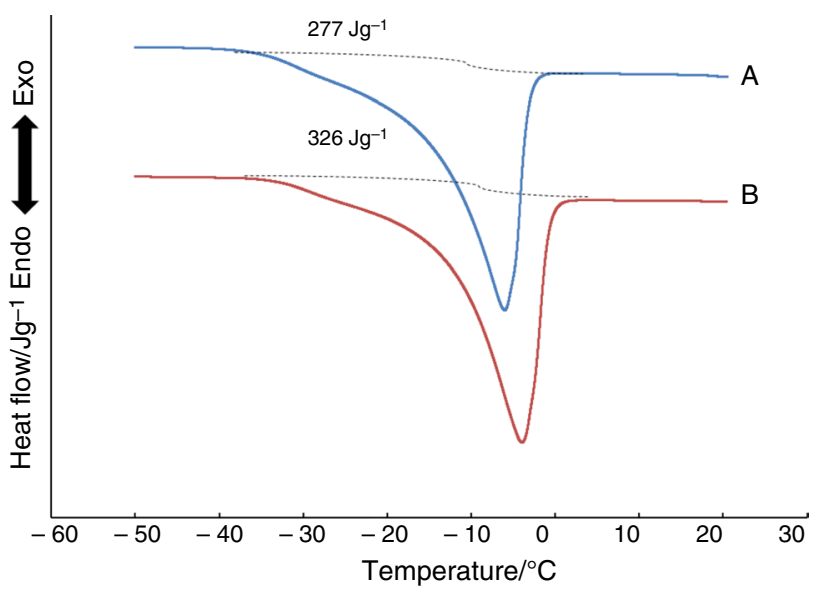

Fig. 3 The DSC curves obtained for naturally grown fruiting bodies (a) and in vitro mycelium (b) of freeze-dried Boletus badius-both samples with a similar water content about $W \mathrm{c} \sim 1.3 \mathrm{~g} \mathrm{~g}^{-1} . \Delta H$ of melting is $277 \mathrm{~J} \mathrm{~g}^{-1}$ and $326 \mathrm{~J} \mathrm{~g}^{-1}$ respectively

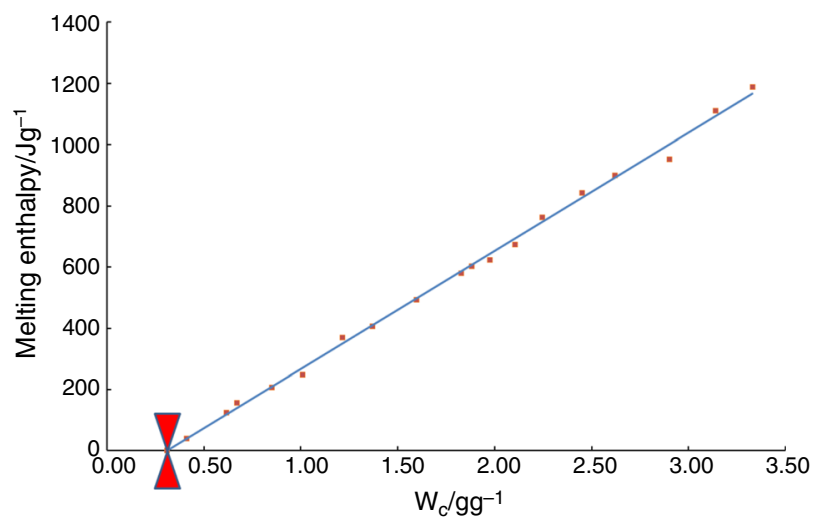

Fig. 4 The determined enthalpies of melting $v s$ respective contents of water $W_{\mathrm{c}}$ represented linear dependences. The non-freezing water NFW values calculated after extrapolation $(\Delta H=0)$ are marked with red sign. The figure shows an example obtained for cultured Agaricus bisporus

Table 1 Contents of nonfreezing water NFW (in $g$ of water per $1 \mathrm{~g}$ of dry mass) determined for mushroom species under study; $\Delta H=a \times W_{\mathrm{c}}+b ; R^{2}$ stands for confidence coefficient

Table 2 Contents of water $N_{\mathrm{ev}}$ determined from evaporation experiments (in $g$ of water per $1 \mathrm{~g}$ of dry mass), calculated for mushroom species under study; $\Delta H=a \times W_{\mathrm{c}}+b ; R^{2}$ stands for confidence coefficient in the samples, the peak of temperature is shifted towards higher temperatures and peak area under the curve increases.

Figure 3 shows some representative examples of DSC runs, obtained from hydrated ( $W_{\mathrm{c}}$ about $1.3 \mathrm{~g} \mathrm{~g}^{-1}$ ) naturally grown fruiting bodies (A) and in vitro mycelium (B) of freeze-dried Boletus badius. It demonstrates differences of melting enthalpies state during the study. One can see that in vitro sample is characterized by higher value of $\Delta H=326 \mathrm{~J} \mathrm{~g}^{-1}$ when compared to commonly cultivated counterpart from natural sources $277 \mathrm{~J} \mathrm{~g}^{-1}$. All other samples behaved similarly.

As it was formerly mentioned, the measured enthalpies of both processes were firstly normalized to the dry mass of mushroom material and then plotted against the respective water concentration $W_{\mathrm{c}}$. Figure 4 shows an appropriate and typical example of such a relationship. One can see a linear increase in the enthalpy with increasing $W_{\mathrm{c}}$. The obtained linear $\Delta H=f\left(W_{\mathrm{c}}\right)$ correlation is strong enough; thus, the nonfreezing NFW can be estimated after extrapolation $\Delta H$ to 0 $(\Delta H=0)$.

A very good fit with the high linear regression was also observed for investigated evaporation processes. The obtained values of NFW and $N_{\text {ev }}$ with parameters of linearization and confidence coefficients $R^{2}$ for all studied samples are listed in Tables 1 and 2. The linear trend was maintained throughout the measuring range.

The content of non-freezing water calculated for all studied mushroom samples was ranging from 0.19 to $0.31 \mathrm{~g} \mathrm{~g}^{-1}$ (Table 1). The highest value was found for cultured fruiting body of $A$. bisporus $\left(0.31 \mathrm{~g} \mathrm{~g}^{-1}\right)$ that fit in with $0.30 \mathrm{~g} \mathrm{~g}^{-1}$ obtained by Guizani et al. [8]. The NFW values of $B$. badius and $C$. Cibarius from same group were smaller and equal to 0.23 and $0.22 \mathrm{~g} \mathrm{~g}^{-1}$ respectively. Whereas the content of non-freezing water is influenced, among others, by the type and concentration of dissolved ions, this disparity may be a result of a different forest and greenhouse substrate composition. The fact that mushrooms are able to accumulate elements from the

\begin{tabular}{|c|c|c|c|c|c|c|}
\hline \multirow[t]{2}{*}{ Mushroom species } & \multicolumn{3}{|c|}{ Cultured or natural origin } & \multicolumn{3}{|l|}{ In vitro cultures } \\
\hline & Parameters $a ; b$ & $R^{2}$ & NFW & Parameters $a ; b$ & $R^{2}$ & NFW \\
\hline Boletus badius & $356.3 ;-82.8$ & 0.9977 & 0.23 & $364.0 ;-69.7$ & 0.9978 & 0.19 \\
\hline Cantharellus cibarius & $361.5 ;-78.3$ & 0.9962 & 0.22 & $400.6 ;-103.5$ & 0.9970 & 0.26 \\
\hline Agaricus bisporus & $384.5 ;-117.6$ & 0.9982 & 0.31 & $369.5 ;-71.8$ & 0.9982 & 0.19 \\
\hline
\end{tabular}

\begin{tabular}{|c|c|c|c|c|c|c|}
\hline \multirow[t]{2}{*}{ Mushroom species } & \multicolumn{3}{|c|}{ Cultured or natural origin } & \multicolumn{3}{|l|}{ In vitro cultures } \\
\hline & Parameters $a ; b$ & $R^{2}$ & $N_{\mathrm{ev}}$ & Parameters $a ; b$ & $R^{2}$ & $N_{\mathrm{ev}}$ \\
\hline Boletus badius & $2525.7 ; 209.7$ & 0.9952 & 0.08 & $2538.7 ; 116.4$ & 0.9975 & 0.05 \\
\hline Cantharellus cibarius & $2292.8 ; 208.8$ & 0.9971 & 0.09 & $2491.9 ; 222.9$ & 0.9958 & 0.09 \\
\hline Agaricus bisporus & $2532.9 ; 180.7$ & 0.9970 & 0.07 & $2282.0 ; 298.7$ & 0.9973 & 0.13 \\
\hline
\end{tabular}


environment explains their attractiveness for researchers. The essential elements are $\mathrm{K}, \mathrm{P}, \mathrm{Mg}, \mathrm{Ca}, \mathrm{Na}, \mathrm{Zn}, \mathrm{Cu}, \mathrm{Mn}$, $\mathrm{Ni}$ and Co. K, $\mathrm{P}$ and $\mathrm{Mg}$ are present at levels of $\mathrm{mg} \mathrm{g}^{-1}$ dry matter (DM), while $\mathrm{Na}, \mathrm{Zn}, \mathrm{Ca}, \mathrm{Fe}, \mathrm{Cu}, \mathrm{Mn}$, etc., are present at $\mu \mathrm{g} \mathrm{g}^{-1} \mathrm{DM}$ [25]. It is clear that the cations with the highest concentration will play a key role in the investigated water-holding processes (Table 3 ).

One can see that the highest total concentration of both potassium, magnesium and sodium can be found for $A$. bisporus. This fact allows to understand why this species is distinguished by the highest NFW. Interestingly, the NFW content of in vitro mycelium was found to be $0.19 \mathrm{~g} \mathrm{~g}^{-1}$ only. It clearly shows that the essence of greenhouse production is associated with rapid growth and high mass of the product. For other mycelium in vitro cultures, the highest NFW content was calculated for $C$. cibarius $\left(0.26 \mathrm{~g} \mathrm{~g}^{-1}\right)$. This fact should be combined with a higher, when compared to the others species, total content of divalent $\mathrm{Mg}, \mathrm{Zn}, \mathrm{Cu}$ and $\mathrm{Fe}$, which is able to be present as di- and trivalent counter-ion as well.

For comparison purposes, the non-freezing water contents calculated for other food materials as cultured fruits, vegetables, meat, fish and bread are collected in Table 4. It can be noted that they are characterized by a large diversity. For example, NFW value of carrot sample was only $0.08 \mathrm{~g} \mathrm{~g}^{-1}$ while of King fish muscles was as much as $0.37 \mathrm{~g} \mathrm{~g}^{-1}$. The meat of a fish has much more NFW than the meat of a wild forest mammal (reindeer) $\left(0.15 \mathrm{~g} \mathrm{~g}^{-1}\right)$, although it is difficult to draw conclusions from two examples only. The non-freezing water-holding behaviour of the vegetables (except for carrot) is ranging from $0.20 \mathrm{~g} \mathrm{~g}^{-1}$ for garlic powder to $0.32 \mathrm{~g} \mathrm{~g}^{-1}$ for broccoli. One can see that those contents are higher than can be found for cultured fruits ranging from $0.16 \mathrm{~g} \mathrm{~g}^{-1}$ for raspberries and mango to $0.27 \mathrm{~g} \mathrm{~g}^{-1}$ for pineapple.
Table 4 Contents of non-freezing water NFW (in $\mathrm{g}$ of water per $1 \mathrm{~g}$ of dry mass) determined for food samples as cultured fruits, vegetables, meat, fish and bread

\begin{tabular}{lll}
\hline Food sample & $\mathrm{NFW} / \mathrm{g} \mathrm{g}^{-1}$ & References \\
\hline Cultured fruits & 0.16 & {$[35]$} \\
Raspberries & 0.16 & {$[36]$} \\
Mango & 0.27 & {$[37]$} \\
Pineapple & 0.20 & {$[38]$} \\
Grape & 0.18 & {$[38]$} \\
Strawberry & 0.22 & {$[39]$} \\
Mature dates & & \\
Cultured vegetables & 0.20 & {$[40]$} \\
Garlic powder & 0.08 & {$[41]$} \\
Carrot & 0.25 & {$[38]$} \\
Onion & 0.32 & {$[42]$} \\
Broccoli & & \\
Meat and fish & 0.15 & {$[41]$} \\
Reindeer meat & 0.37 & {$[43]$} \\
King fish whole muscle & & \\
Other & 0.23 & {$[41]$} \\
White bread & &
\end{tabular}

Comparing to non-freezing water, the effect of ions on the contents of $N_{\mathrm{ev}}$ is associated with different mechanism. Průšovă et al. [31] pointed out that the presence of ions with fixed dimension and surface charge makes the structure more "rigid". This confirms earlier research [44] associated with the influence of pore ("nanocavities") size on the character and quantity of water in the non-freezing water layer. Due to the presence of ions, each nanocavity has a stable diameter. The more the cations, the more pores with a fixed diameter can be found. In other words and temporarily excluding the effect of water binding by

Table 3 Contents of elements in dried fruiting bodies and in vitro mycelium of Boletus badius, Cantharellus cibarius and Agaricus bisporus

\begin{tabular}{|c|c|c|c|c|c|c|c|}
\hline $\begin{array}{l}\text { Mushroom } \\
\text { species }\end{array}$ & Origin & $\mathrm{Cu} / \mu \mathrm{g} \mathrm{g}^{-1} \mathrm{DW}$ & $\mathrm{Mg} / \mu \mathrm{g} \mathrm{g}^{-1} \mathrm{DW}$ & $\mathrm{Zn} / \mu \mathrm{g} \mathrm{g}^{-1} \mathrm{DW}$ & $\mathrm{Fe} / \mu \mathrm{g} \mathrm{g}^{-1} \mathrm{DW}$ & $\mathrm{Na} / \mu \mathrm{g} \mathrm{g}^{-1} \mathrm{DW}$ & $\mathrm{K} / \mu \mathrm{g} \mathrm{g}^{-1} \mathrm{DW}$ \\
\hline \multirow[t]{2}{*}{ A. bisporus } & Fruiting bodies & $\begin{array}{l}34.50 \pm 11.78 \\
{[24]}\end{array}$ & $\begin{array}{l}1735.10 \pm 419.22 \\
{[24]}\end{array}$ & $82.91 \pm 23.33[24]$ & $82.39 \pm 51.84$ & $760-860[22]$ & $\begin{array}{l}59,000 \pm 2000 \\
{[25]}\end{array}$ \\
\hline & $\begin{array}{l}\text { In vitro myce- } \\
\text { lium }\end{array}$ & $10.51 \pm 6.28[24]$ & $458.54 \pm 96.71$ & $\begin{array}{l}146.10 \pm 30.19 \\
{[24]}\end{array}$ & $\begin{array}{l}141.39 \pm 57.32 \\
{[24]}\end{array}$ & $2000[24]$ & $5900[34]$ \\
\hline \multirow[t]{2}{*}{ C. cibarius } & Fruiting bodies & $43.57 \pm 3.90[23]$ & $\begin{array}{l}1004.00 \pm 64.72 \\
{[23]}\end{array}$ & $95.46 \pm 9.98[23]$ & $\begin{array}{l}402.33 \pm 105.13 \\
{[23]}\end{array}$ & $83 \pm 51[25]$ & $\begin{array}{l}56,000 \pm 2000 \\
{[25]}\end{array}$ \\
\hline & $\begin{array}{l}\text { In vitro myce- } \\
\quad \text { lium }\end{array}$ & $12.47 \pm 8.41[23]$ & $\begin{array}{l}541.67 \pm 113.01 \\
{[23]}\end{array}$ & $\begin{array}{l}131.93 \pm 21.57 \\
{[23]}\end{array}$ & $\begin{array}{l}457.9 \pm 173.82 \\
{[23]}\end{array}$ & $200[23]$ & $5600[34]$ \\
\hline \multirow[t]{2}{*}{ B. badius } & Fruiting bodies & $\begin{array}{l}43.55 \pm 10.16 \\
{[23]}\end{array}$ & $906.42 \pm 88.18[23]$ & $\begin{array}{l}172.08 \pm 29.76 \\
{[23]}\end{array}$ & $\begin{array}{l}256.75 \pm 106.91 \\
{[23]}\end{array}$ & $470 \pm 70[25]$ & $\begin{array}{l}43,000 \pm 2000 \\
{[25]}\end{array}$ \\
\hline & $\begin{array}{l}\text { In vitro myce- } \\
\text { lium }\end{array}$ & $4.17 \pm 1.09$ [23] & $\begin{array}{l}928.92 \pm 103.94 \\
{[23]}\end{array}$ & $\begin{array}{l}442.70 \pm 174.11 \\
{[23]}\end{array}$ & $\begin{array}{l}693.48 \pm 405.47 \\
{[23]}\end{array}$ & - & $4300[34]$ \\
\hline
\end{tabular}

$D W$ stands for dry weight; some data are presented as the mean \pm SD 
hydrogen bonds, if the size of pore is small enough, such a space can trap water molecules more firmly and for that reason the enthalpy of evaporation is larger than if the size of pore is larger. In such a situation, enthalpy of evaporation is accordingly smaller, because water molecules can desorb from the matrix more easily.

In the group of mushrooms of cultured or natural origin, the appropriate values of $N_{\mathrm{ev}}$ were comparable and were $0.08,0.09$ and $0.07 \mathrm{~g} \mathrm{~g}^{-1}$ for Boletus badius, Cantharellus cibarius and Agaricus bisporus, respectively (Table 2). Calculated amounts lead to the conclusion that the internal structure formed by the fungal polysaccharide chains, in combination with the concentration of cations and relatively low NFW values, created conditions favourable easy desorption of water molecules from the matrix.

With the exception of $A$. bisporus, very similar $N_{\mathrm{ev}}$ values were obtained in the group of in vitro mycelium - 0.05 and $0.09 \mathrm{~g} \mathrm{~g}^{-1}$ for B. badius and C. cibarius, respectively. However, A. bisporus is an example that confirms the correctness of previously observed relationships. The calculated amount of water associated with the evaporation process was equal to $0.13 \mathrm{~g} \mathrm{~g}^{-1}$. This is understandable because the samples from this material had the highest total content of cations as well as the highest content of NFW.

Similar studies for other food materials have not been met in the literature.

\section{Conclusions}

The contents of non-freezing water NFW and water associated with the evaporation process $N_{\mathrm{ev}}$ of lyophilized in vitro mycelium and commonly cultivated mushrooms Agaricus bisporus, Boletus badius and Cantharellus cibarius were successfully estimated using a new, in this area of biological samples, differential scanning calorimetry technique. The obtained results were variable and highly dependent on fungus species, origin (in vitro mycelium or cultivated) and content of accumulated metals ions. It was stated that the concentration of NFW increased with the increase in the content of cations. Measured amounts of $N_{\text {ev }}$ were low for all investigated samples, suggesting that the non-freezing water consists mostly of water molecules interacting with sorption sites not trapped in pores.

The above-mentioned water contents are important components of the state diagram, which could be used in identifying mushroom stability during storage or selecting suitable conditions of temperature and moisture content for processing.

\section{Compliance with ethical standards}

Conflict of interest The authors Przemysław Talik, Joanna Piwowarczyk, Bożena Muszyńska and Urszula Hubicka declare that they have no conflict of interest.

Ethical approval This article does not contain any studies with human participants or animals performed by any of the authors.

Informed consent Informed consent is not applicable in this study.

Open Access This article is licensed under a Creative Commons Attribution 4.0 International License, which permits use, sharing, adaptation, distribution and reproduction in any medium or format, as long as you give appropriate credit to the original author(s) and the source, provide a link to the Creative Commons licence, and indicate if changes were made. The images or other third party material in this article are included in the article's Creative Commons licence, unless indicated otherwise in a credit line to the material. If material is not included in the article's Creative Commons licence and your intended use is not permitted by statutory regulation or exceeds the permitted use, you will need to obtain permission directly from the copyright holder. To view a copy of this licence, visit http://creativecommons.org/licenses/by/4.0/.

\section{References}

1. Levine H, Slade L. A polymer physico-chemical approach to the study of commercial starch hydrolysis products (SHPs). Carbohydr Polym. 1986;6(3):213-44. https://doi.org/10.1016/01448617(86)90021-4.

2. Slade L, Levine H, Ievolella J, Wang M. The glassy state phenomenon in applications for the food industry: application of the food polymer science approach to structure-function relationships of sucrose in cookie and cracker systems. J Sci Food Agric. 1993;63(2):133-76. https://doi.org/10.1002/jsfa.2740630202.

3. Kokini JL, Cocero AM, Madeka H, De Graaf E. The development of state diagrams for cereal proteins. Trends Food Sci Technol. 1994;5:281-8. https://doi.org/10.1016/0924-2244(94)90136-8.

4. Roos Y. Characterization of food polymers using state diagrams. J Food Eng. 1995;24:339-60. https://doi.org/10.1016/02608774(95)90050-L.

5. Rahman MS. State diagram of foods: its potential use in food processing and product stability. Trends Food Sci Technol. 2006;17:129-41. https://doi.org/10.1016/j.tifs.2005.09.009.

6. Rahman MS. Food stability determination by macro-micro region concept in the state diagram and by defining a critical temperature. J Food Eng. 2010;99(4):402-16. https://doi.org/10.1016/j.jfood eng.2009.07.011.

7. Guizani N, Al-Saidi GS, Rahman MS, Bornaz S, Al-Alawi AA. State diagram of dates: glass transition, freezing curve and maximal-freeze-concentration condition. J Food Eng. 2010;99(1):92-7. https://doi.org/10.1016/j.jfoodeng.2010.02.003.

8. Guizani N, Rahman MS, Klibi M, Al-Rawahi A, Bornaz S. Thermal characteristics of Agaricus bisporus mushroom: freezing point, glass transition, and maximal-freeze-concentration condition. Int Food Res J. 2013;20(4):1945-52.

9. Herawat H, Kusnandar F, Adawiyah DR, Budijanto S, Rahman MS. Thermal characteristics and state diagram of extruded instant artificial rice. Thermochim Acta. 2014;593:50-7. https://doi. org/10.1016/j.tca.2014.08.017. 
10. Rahman MS. Applications of macro-micro region concept in the state diagram and critical temperature concepts in determining the food stability. Food Chem. 2012;132:1679-85. https://doi. org/10.1016/j.foodchem.2011.09.092.

11. Ping ZH, Nguyen QT, Chen SM, Zhou JQ, Ding YD. States of water in different hydrophilic polymers: DSC and FTIR studies. Polymer. 2001;42:8461-7. https://doi.org/10.1016/S0032 -3861(01)00358-5.

12. Wolfe J, Bryant G, Koster KL. What is 'unfreezable water', how unfreezable is it and how much is there? CryoLetters. 2002;23:157-66.

13. Hatakeyama T, Nakamura K, Hatakeyama H. Vaporization of bound water associated with cellulose fibres. Thermochim Acta. 2000;352-352:233-9. https://doi.org/10.1016/S0040 $-6031(99) 00471-2$.

14. Talik P, Hubicka U. The DSC approach to study non-freezing water contents of hydrated hydroxypropylcellulose (HPC): a study over effects of viscosity and drug addition. J Therm Anal Calorim. 2018;132(1):445-51. https://doi.org/10.1007/s10973-017-6889-9.

15. Berthold J, Desbrières J, Rinaudo M, Salmén L. Types of adsorbed water in relation to the ionic groups and their counter-ions for some cellulose derivatives. Polymer. 1994;35:5729-36. https://doi. org/10.1016/S0032-3861(05)80048-5.

16. Hatakeyama $\mathrm{H}$, Hatakeyama $\mathrm{T}$. Interaction between water and hydrophilic polymers. Thermochim Acta. 1998;308:3-22. https:// doi.org/10.1016/S0040-6031(97)00325-0.

17. Hatakeyama T, Nakamura K, Hatakeyama H. Determination of bound water content in polymers by DTA, DSC and TG. Thermochim Acta. 1985;123:153-61. https://doi.org/10.1016/00406031(88)80018-2.

18. Kučerík J, Průšová A, Šmejkalová D, Velebný V. Response to “a note on an alternative DSC approach to study hydration of hyaluronan”. Carbohydr Polym. 2013;98(2):1561-4. https://doi. org/10.1016/j.carbpol.2013.07.049.

19. Rudawska M, Leski T. Macro- and microelement contents in fruiting bodies of wild mushrooms from the Notecka forest in west-central Poland. Food Chem. 2005;92(3):499-506. https://doi.org/10.1016/j. foodchem.2004.08.017.

20. Mleczek M, Magdziak Z, Gąsecka M, Niedzielski P, Kalač P, Siwulski M, Rzymski P, Zalicka S, Sobieralski K. Content of selected elements and low-molecular-weight organic acids in fruiting bodies of edible mushroom Boletus badius (Fr.) Fr. from unpolluted and polluted areas. Environ Sci Pollut R. 2016;23(20):20609-18. https ://doi.org/10.1007/s11356-016-7222-z.

21. Kojta AK, Falandysz J. Metallic elements $(\mathrm{Ca}, \mathrm{Hg}, \mathrm{Fe}, \mathrm{K}, \mathrm{Mg}$, $\mathrm{Mn}, \mathrm{Na}, \mathrm{Zn})$ in the fruiting bodies of Boletus badius. Food Chem. 2016;200(1):206-14. https://doi.org/10.1016/j.foodc hem.2016.01.006.

22. Muszyńska B, Kała K, Rojowski J, Grzywacz A, Opoka W. Composition and biological properties of Agaricus bisporus fruiting bodies: a review. Pol J Food Nutr Sci. 2017;67(3):173-81. https://doi. org/10.1515/pjfns-2016-0032.

23. Reczyński W, Muszyńska B, Opoka W, Sułkowska-Ziaja K, Malec M. Comparative study of metals accumulation in cultured in vitro mycelium and naturally grown fruiting bodies of Boletus badius and Cantharellus cibarius. Biol Trace Elem Res. 2013;153(1-3):355-62. https://doi.org/10.1007/s12011-013-9670-3.

24. Muszyńska B, Krakowska A, Sułkowska-Ziaja K, Opoka W, Reczyński W, Baś B. In vitro cultures and fruiting bodies of culinary-medicinal Agaricus bisporus (white button mushroom) as a source of selected biologically-active elements. J Food Sci Technol. 2015;52(11):7337-44. https://doi.org/10.1007/s13197-015-1830-3.

25. Falandysz J, Szymczyk K, Ichihashi H, Bielawski L, Gucia M, Frankowska A, Yamasaki S. ICP/MS and ICP/AES elemental analysis (38 elements) of edible wild mushrooms growing in Poland. Food
Addit Contam. 2001;18(6):503-13. https://doi.org/10.1080/02652 030119625.

26. Gąsecka M, Siwulski M, Mleczek M. Evaluation of bioactive compounds content and antioxidant properties of soil-growing and wood-growing edible mushrooms. J Food Process Preserv. 2018;42(1):e13386. https://doi.org/10.1111/jfpp.13386.

27. Zhang L, Hu Y, Duan X, Tang T, Shen Y, Hu B, Liu A, Chen H, $\mathrm{Li} \mathrm{C}$, Liu Y. Characterization and antioxidant activities of polysaccharides from thirteen boletus mushrooms. Int J Biol Macromol. 2018;113(1):1-7. https://doi.org/10.1016/j.ijbiomac.2018.02.084+.

28. Muszyńska B, Kała K, Firlej A, Sułkowska-Ziaja K. Cantharellus cibarius: culinary-medicinal mushroom content and biological activity. Acta Pol Pharm. 2016;73(3):589-98.

29. Liu J, Cowman MK. Thermal analysis of semi-dilute hyaluronan solutions. J Therm Anal Calorim. 2000;59:547-57. https://doi. org/10.1023/A:101011421.

30. Mlčoch T, Kučerík J. Hydration and drying of various polysaccharides studied using DSC. J Therm Anal Calorim. 2013;113(3):117785. https://doi.org/10.1007/s10973-013-2946-1.

31. Průšovă A, Šmejkalovă D, Chytil M, Velebný V, Kučerík J. An alternative DSC approach to study hydration of hyaluronan. Carbohydr Polym. 2010;82:498-503. https://doi.org/10.1016/j.carbp ol.2010.05.022.

32. Talik P, Hubicka U. A study of the drying behaviour of various types of hydrated hydroxypropyl cellulose (HPC) and their mixtures with drugs of different solubility using DSC. J Therm Anal Calorim. 2019. https://doi.org/10.1007/s10973-019-09153-0.

33. Park S, Venditti RA, Jameel H, Pawlak JJ. Studies of the heat of vaporization of water associated with cellulose fibers characterized by thermal analysis. Cellulose. 2007;14:195-204. https://doi. org/10.1007/s10570-007-9108-1.

34. Falandysz J, Borovička J. Macro and trace mineral constituents and radionuclides in mushrooms: health benefits and risks. Appl Microbiol Biotechnol. 2013;97(2):477-501. https://doi.org/10.1007/s0025 3-012-4552-8.

35. Syamaladevi RM, Sablani SS, Tang J, Powers J, Swanson BG. State diagram and water adsorption isotherm of raspberry (Rubus idaeus). J Food Eng. 2009;91(3):460-7. https://doi.org/10.1016/j. jfoodeng.2008.09.025.

36. Zhao JH, Liu F, Wen X, Xiao HW, Ni YY. State diagram for freezedried mango: freezing curve, glass transition line and maximalfreeze-concentration condition. J Food Eng. 2015;157:49-56. https ://doi.org/10.1016/j.jfoodeng.2015.02.016.

37. Telis VRN, Sobral PJA. Glass transitions and state diagram for freeze-dried pineapple. LWT-Food Sci Technol. 2001;34:199-205. https://doi.org/10.1006/fstl.2000.0685.

38. Sa MM, Sereno AM. Glass transitions and state diagrams for typical natural fruits and vegetables. Thermochim Acta. 1994;246:285-97. https://doi.org/10.1016/0040-6031(94)80096-0.

39. Rahman MS. State diagram of date flesh using differential scanning calorimetry (DSC). Int J Food Prop. 2004;7:407-28. https:// doi.org/10.1081/JFP-200032930.

40. Rahman MS, Sablani SS, Al-Habsi N, Al-Maskri S, Al-Belushi R. State diagram of freeze-dried garlic powder by differential scanning calorimetry and cooling curve methods. J Food Sci. 2005;70(2):E135-41. https://doi.org/10.1111/j.1365-2621.2005. tb07086.x.

41. Roos YH. Phase transitions and unfreezable water content of carrots, reindeermeat and white bread studied using differential scanning calorimetry. J Food Sci. 1986;51(3):684-6. https://doi. org/10.1111/j.1365-2621.1986.tb13911.x.

42. Suresh S, Al-Habsi N, Guizani N, Rahman MS. Thermal characteristics and state diagram of freeze-dried broccoli: freezing curve, maximal-freeze-concentration condition, glass line and solids-melting. Thermochim Acta. 2017;655:129-36. https://doi.org/10.1016/j. tca.2017.06.015. 
43. Sablani SS, Rahman MS, AI-Busaidi S, Guizani N, AI-Habsi N, AI-Belushi R, Soussi B. Thermal transitions of king fish whole muscle, fat and fat-free muscle by differential scanning calorimetry. Thermochim Acta. 2007;462:56-63. https://doi.org/10.1016/j. tca.2007.06.008.

44. Liu GL, Yao KD. What causes the unfrozen water in polymers: hydrogen bonds between water and polymer chains? Polymer. 2001;42:3943-7.
Publisher's Note Springer Nature remains neutral with regard to jurisdictional claims in published maps and institutional affiliations. 